\title{
Heterogeneity of HLA-DR-positive histiocytes in human intestinal lamina propria: a combined histochemical and immunohistological analysis
}

\author{
WS SELBY, LW POULTER, S HOBBS, DP JEWELL, G JANOSSY
}

\begin{abstract}
From the Department of Gastroenterology, John Radcliffe Hospital, Oxford, and Department of Immunology, Royal Free Hospital School of Medicine, London
\end{abstract}

SUMMARY HLA-DR-positive histiocytes in the lamina propria of the human intestine have been characterised using combined histochemical and immunohistological techniques. In the small intestine, $80-90 \%$ of the HLA-DR ${ }^{+}$histiocytes had irregular surfaces with stellate processes, and exhibited strong membrane adenosine triphosphatase (ATPase) activity, but weak acid phosphatase (ACP) and non-specific esterase (NSE) activities (HLA-DR ${ }^{+} \mathrm{ACP}^{+1-} \mathrm{NSA}^{+1-} \mathrm{ATP}^{++}$; type 1 cell). In contrast, in the lamina propria of the colon the majority $(60-70 \%)$ of HLA-DR ${ }^{+}$ cells were large, round cells with strong ACP and NSE activities but no detectable ATPase activity ( $\mathrm{HLA}-\mathrm{DR}^{+} \mathrm{ACP}^{++} \mathrm{NSE}^{++} \mathrm{ATP}^{+/-}$; type 2 cell). The colon also contained a population of type 1 cells $(30-40 \%)$. In active inflammatory bowel disease affecting the colon a third population of $\mathrm{HLA}_{-} \mathrm{DR}^{+}$histiocytes was seen. These cells were irregular in outline, with many processes, and were $\mathrm{ACP}^{++} \mathrm{NSE}^{+} \mathrm{ATP}^{+1-}$ (type 3 cell). The type 3 cells appeared to replace type 2 cells. After treatment, the appearances returned to normal.

These findings suggest that the different populations of HLA-DR ${ }^{+}$histiocytes in the human intestine may have several functions, reflecting the different forms of antigen present in the intestine. The alterations in inflammatory bowel disease may represent activation in response to an invading antigen.

Within the lamina propria of the human small and large intestine are many histiocytic-type cells which exhibit strong expression of HLA-DR (Ia-like) antigens. ${ }^{12}$ These cells are found in the villi of the small intestine and in the subepithelial region of the colon. These sites correspond to those previously described for intestinal macrophages. ${ }^{34}$

HLA-DR $^{+}$macrophage-like cells identified in other tissues have been shown to represent a heterogeneous population, comprised of such cells as the Langerhans cells in the skin, ${ }^{5}$ the interdigitating (ID) cells of lymph nodes and spleen, ${ }^{67}$ cortical cells of the thymus ${ }^{8}$ and inflammatory cells in the synovial membrane. ${ }^{9}$ Histochemistry has been of value in defining the characteristics of several cell populations and particularly in the discrimination of specific cell types of the monocyte-macrophage series. ${ }^{11} 11$ Indeed, the demonstration of acid phosphatase in inflammatory macrophages and of adenosine triphosphatase activity in interdigitating, antigen-presenting cells, ${ }^{12}{ }^{13}$ has now been shown to

Accepted for publication 15 September 1982 be of considerable value in differentiating these two cell types, both of which are HLA-DR ${ }^{+}$, in normal and pathological tissues. ${ }^{14}$

In order to characterise the HLA-DR ${ }^{+}$histiocytes in human intestinal lamina propria we have examined the activities of acid phosphatase (ACP), non-specific esterase (NSE) and adenosine triphosphatase (ATPase) in frozen sections of normal and diseased intestine. Double enzyme techniques and the combination of immunofluorescence and cytochemistry on the same section has allowed us to demonstrate that the intestinal HLA-DR-positive population is indeed heterogeneous. This heterogeneity may have functional significance both in normal intestine and in that of patients with gastrointestinal disease, such as ulcerative colitis or Crohn's disease.

\section{Material and methods}

SUBJECTS AND TISSUES

Proximal small intestinal biopsies were obtained by peroral suction from one normal subject and from 
three patients undergoing investigation for diarrhoea. Ileal or colonic tissue, or both, was taken endoscopically or at laparotomy from seven patients with either colonic neoplasia or the irritable colon syndrome. All specimens were histologically normal as shown by study of frozen or formalin-fixed sections. Five patients with ulcerative colitis (active in three, inactive in two) and one with active Crohn's disease were also studied. Four of the patients were receiving corticosteroids and three were taking sulphasalazine. The specimens were orientated on cork, covered with OCT compound (Ames Co) and frozen in isopentane suspended over liquid nitrogen. They were stored in liquid nitrogen until used.

\section{IMMUNOFLUORESCENCE}

HLA-DR antigens were detected by an antiserum raised in chickens ${ }^{15}$ using a rhodamine-conjugated second layer antiserum. In several sections the anti-HLA-DR antiserum was used in combination with antisera to human $\operatorname{IgA}$, IgM or IgG or with a monoclonal antibody to human leucocyte antigen (2D1) in a double marker immunofluorescence technique described in full elsewhere. ${ }^{16}$ Tissue sections were also studied using the monoclonal antibody NA1/34 which reacts with cortical thymocytes as well as Langerhans cells. ${ }^{14}{ }^{17}$ Immunofluorescence was detected using a Standard 14 Zeiss microscope with IV F1 epifluorescence condenser. Selective filters for rhodamine and fluorescein enabled simultaneous detection of HLA-DR antigens and Ig subclass on the same section.

\section{HISTOCHEMISTRY}

Histochemical methods for detecting ACP, NSE and ATPase have been described in full elsewhere. ${ }^{14}$ Briefly, the pararosaniline method for ACP was used. This involves incubation of the slides in a medium containing the substrate naphthol ASBI phosphate and used hexazotised pararosaniline as a simultaneous coupler. The lead precipitation

Characteristics of $H L A-D R^{+}$histiocytes in the human intestinal lamina propria

\begin{tabular}{|c|c|c|c|c|c|}
\hline & $\%$ & Morphology & $A C P$ & A TPase & Type \\
\hline $\begin{array}{l}\text { Small } \\
\text { intestine }\end{array}$ & $\begin{array}{l}80-90 \\
10-20\end{array}$ & $\begin{array}{l}\text { small, stellate } \\
\text { large, round }\end{array}$ & $\begin{array}{l}+1- \\
++\end{array}$ & $\begin{array}{l}++ \\
+1-\end{array}$ & $\begin{array}{l}1 \\
2\end{array}$ \\
\hline $\begin{array}{l}\text { Large } \\
\text { intestine }\end{array}$ & $\begin{array}{l}6()-70 \\
3()-40\end{array}$ & $\begin{array}{l}\text { large, round } \\
\text { small, stellate }\end{array}$ & $\begin{array}{l}++ \\
+1-\end{array}$ & $\begin{array}{l}+1- \\
++\end{array}$ & $\begin{array}{l}2 \\
1\end{array}$ \\
\hline $\begin{array}{l}\text { Active } \\
\text { IBD }\end{array}$ & $\begin{array}{l}50-60 \\
30-40 \\
10-20\end{array}$ & $\begin{array}{l}\text { small, irregular } \\
\text { small, stellate } \\
\text { large, round }\end{array}$ & $\begin{array}{l}++ \\
+1- \\
++\end{array}$ & $\begin{array}{l}+1- \\
++ \\
+1-\end{array}$ & $\begin{array}{l}3 \\
1 \\
2\end{array}$ \\
\hline
\end{tabular}

IBD = inflammatory bowel disease method was used to detect ATPase. This used adenosine triphosphate as a substrate and lead nitrate as a coupler; sections were developed after incubation in a solution of ammonium sulphide. Staining for these two enzymes was done separately as well as in combination on the one section. Staining for ACP was also combined with immunofluorescence for HLA-DR antigens on the same section. In this case, the Gomori lead method for ACP was used ${ }^{18}$ as the pararosaniline method resulted in considerable autofluorescence. The two methods for ACP gave similar results. Non-specific esterase activity was detected using $\alpha$ naphthyl acetate as a substrate.

\section{Results}

SMALL INTESTINE (TABLE)

HLA-DR-positive histiocytic cells occurred predominantly in the villi. Double-labelling with the antiIg antisera confirmed that these cells were neither plasma cells nor B lymphocytes. In the small intestine approximately $80-90 \%$ of the cells were small, stellate cells with processes extending from the cell surface (Fig. 1a). Cytochemical analysis demonstrated that this cell type expressed strong membrane activity of ATPase, while activity of ACP was either weak or negative (Fig. 2a). Activity of NSE was similar to that of ACP. This type of cell (HLA-DR ${ }^{+}$ $\mathrm{ACP}^{+/-} \mathrm{NSE}^{+/-} \mathrm{ATP}^{++}$) was designated type 1. A smaller proportion of the HLA-DR ${ }^{+}$histiocytes (approximately 10-20\%) were large and round in appearance and had strong cytoplasmic ACP and NSE activities but weak or negative ATPase activity. This cell type (HLA-DR ${ }^{+} \mathrm{ACP}^{++} \mathrm{NSE}^{++}$ $\mathrm{ATP}^{+/-}$) was designated type 2 . Of some interest was the observation that in some of the HLA-DR ${ }^{+}$ cells the distribution of the HLA-DR antigens appeared to be cytoplasmic as well as membraneassociated.

In the ileum, most of the villi contained type 1 cells. However, in one of the ileal specimens, from a patient with the irritable colon syndrome, there were occasional villi which were packed with type 2 cells.

Combined analysis of HLA-DR antigens and ACP clearly identified the HLA-DR ${ }^{+}$histiocytes, but these were only infrequently $\mathrm{ACP}^{+}$.

\section{LARGE INTESTINE}

In the lamina propria of the colon HLA-DR ${ }^{+}$histiocytes were concentrated subepithelially in clusters (Fig. 1b). They did not label with antisera to the Ig subclasses. In contrast to the findings in the small intestine, the majority of HLA-DR ${ }^{+}$histiocytes in the colon (approximately 60-70\%; Table) were of 

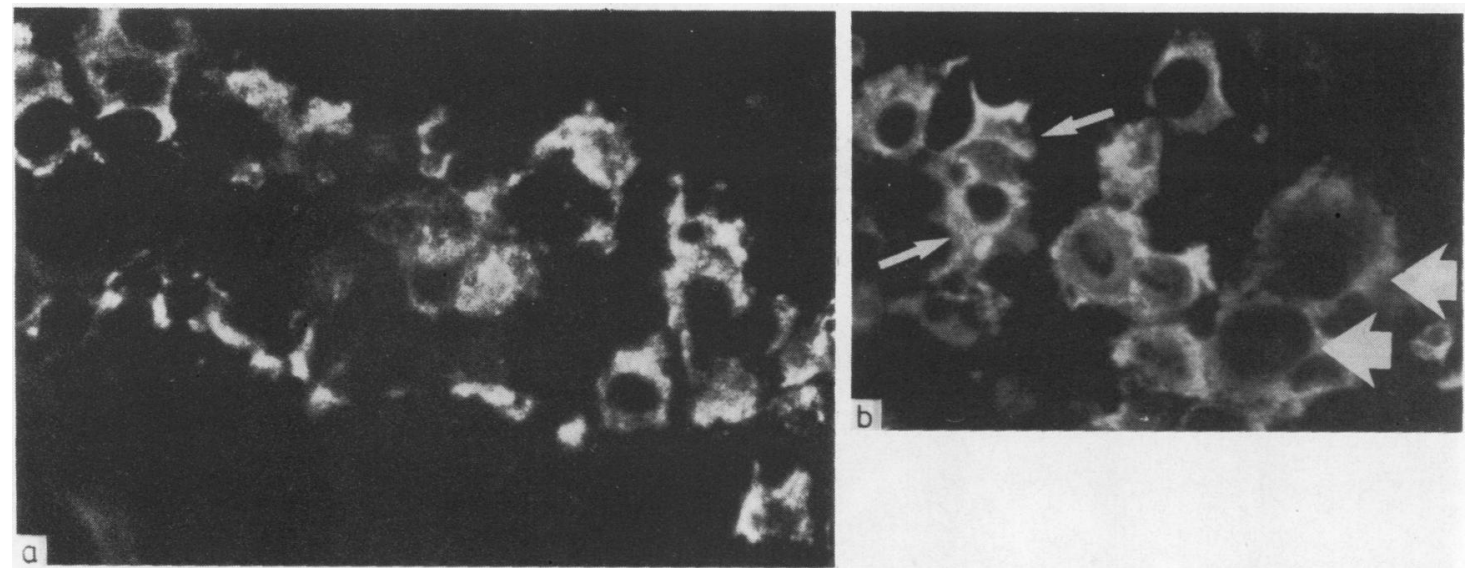

Fig. $1 \quad H L A-D R$ antigens in human intestinal mucosa. (a) Small intestine: the $H L A-D R^{+}$histiocytes in the lamina propria are irregular in shape and show heterogeneity of size. (b) Large intestine: Many $H L A-D R^{+}$cells are large and round (type $2=$ large arrows). Smaller, irregular cells are also seen (type $1=$ small arrows) $\times 400$
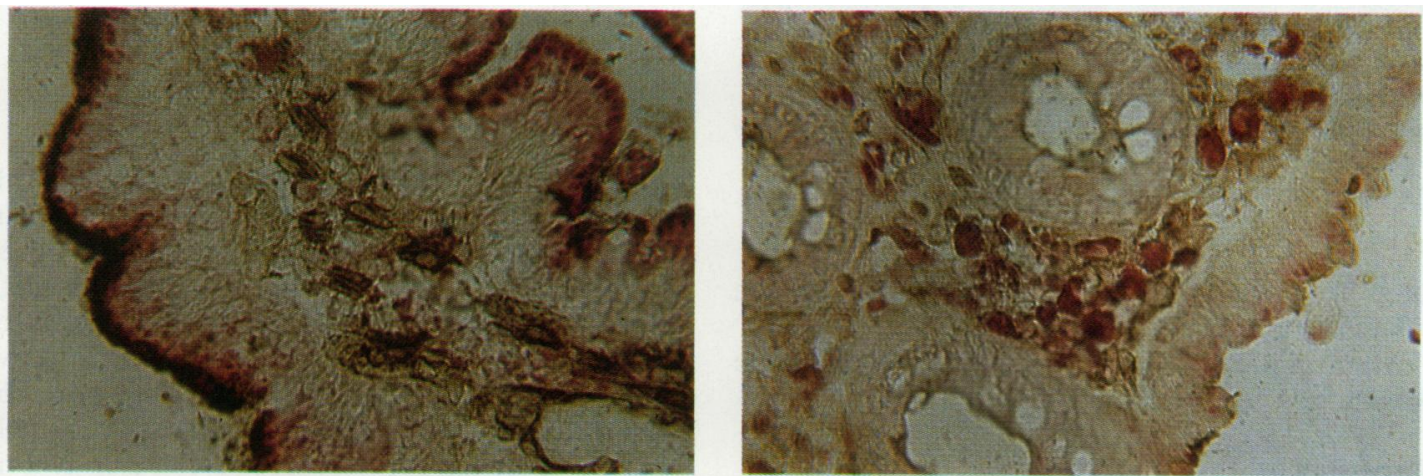

Fig. 2 Double histochemical analysis for ACP and ATPase. (a) In the normal small intestine histiocytes with membrane ATPase activity predominate (type 1; cells with brown reaction product). There are occasional cells with strong cytoplasmic $A C P$ activity (red reaction product). (b) In the colon most of the histiocytes are large, round cells with strong ACP activity (type 2 cells; red reaction product). There are also a few type 1 cells (brown reaction product).

the large, round type, with strong ACP and NSE activities but weak or undetectable ATPase activity (type 2 cells). Thirty to $40 \%$ of $\mathrm{HLA}^{-\mathrm{DR}^{+}}$cells were type 1 cells (Fig. 2b). All of the cells with strong ACP activity were also HLA-DR ${ }^{+}$and, conversely, all large, round HLA-DR ${ }^{+}$cells had strong ACP activity.

Caecal biopsies were examined from the patients in whom ileal tissue was studied. In each case, type 2 cells predominated in the caecum and type 1 cells predominated in the ileum (see above).

Both in the small intestine and in the large intestine, the HLA-DR ${ }^{+}$cells showed weak reactivity with $2 \mathrm{D} 1$, but were NA1/34-.

INFLAMMATORY BOWEL DISEASE

When sections of colonic biopsies from patients with ulcerative colitis or Crohn's disease were studied it was found that the characteristics of the HLA-DR ${ }^{+}$ histiocytes were clearly different from those seen in the normal large intestine. The majority of the cells were irregular in outline with many elongated processes (Fig. 3) and, unlike the histiocytes in the small intestine, had strong cytoplasmic ACP activity but weak or no ATPase activity (Fig. 4, Table). NSE activity was variable. This cell type was designated type 3 . Type 2 cells appeared to be considerably reduced in number, making up some $10-20 \%$ of the HLA-DR ${ }^{+}$population in the inflamed colon. Type 1 cells were present in proportions similar to those seen in the normal colon. The HLA-DR ${ }^{+}$histiocytes in the colon of patients with inflammatory bowel disease were not clustered but rather were scattered diffusely throughout the subepithelial region, sepa- 


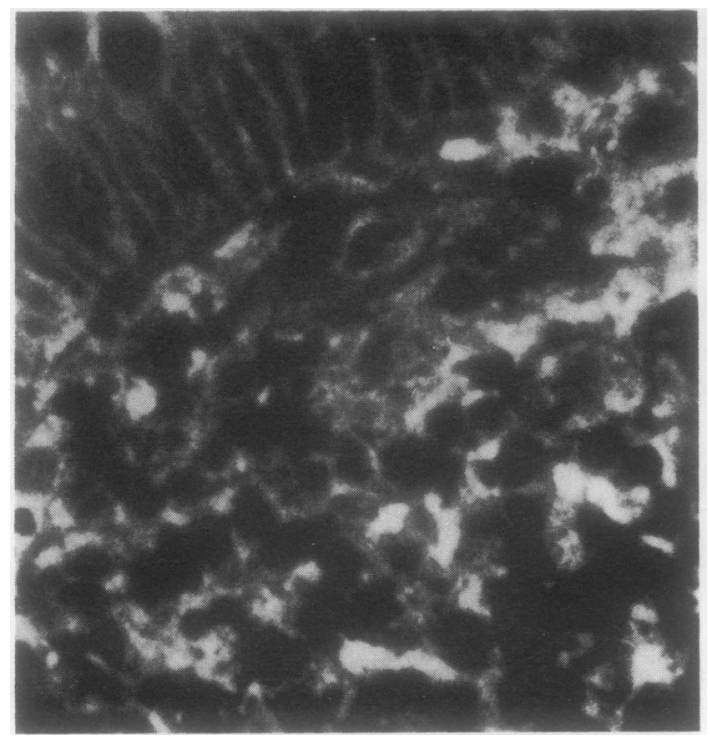

Fig. 3 Colonic biopsy from a patient with active Crohn's colitis, showing the distribution of HLA-DR antigens. The $H L A-D R^{+}$histiocytes appear small and irregular.

Individual cell outlines are difficult to distinguish, and there are many processes extending throughout the lamina propria. The colonic epithelium is also $H L A-D R^{+} \times 400$

rated from each other by oedema and by the inflammatory cell infiltrate.

After treatment, the HLA-DR-positive histiocyte populations returned to normal.

\section{Discussion}

The combination of immunofluorescent and histochemical analysis of tissue sections had indicated that there are at least two populations of HLA-DR ${ }^{+}$ histiocytic-type cells within the normal lamina propria. In the small intestine the majority of these cells are $\mathrm{ATPase}^{++} \mathrm{ACP}^{+/-} \mathrm{NSE}^{+/-}$and are relatively small with a stellate appearance (type 1). In the colon, large, round HLA-DR ${ }^{+}$cells predominate. They are $\mathrm{ACP}^{++} \mathrm{NSE}^{++} \mathrm{ATPase}^{+-}$(type 2).

Several workers have examined the histochemical characteristics of the human small intestine $e^{49-21}$ and large intestine. ${ }^{22}$ These studies confirmed our findings with respect to ACP activity, although results for other enzymes were inconsistent. In the most comprehensive study, Riecken et $a_{2}^{\prime 23}$ described histochemical characteristics of small intestinal macrophages similar to those observed in the present study. However, they made no mention of macrophage morphology, nor did they examine the distribution of HLA-DR antigens.

It is now well established that cells of the "mac-

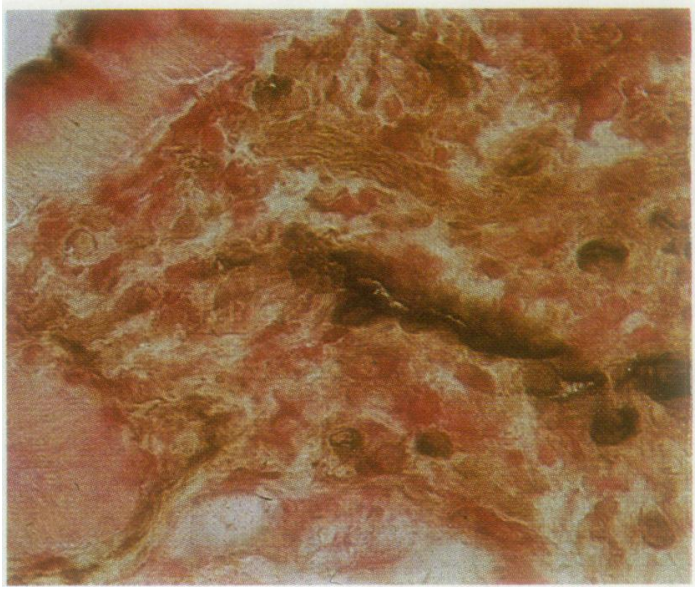

Fig. 4 Colonic biopsy from a patient with active ulcerative colitis, showing ACP and ATPase activities. Most of the $A C P^{+}$lamina propria histiocytes are smaller and more irregular than in normal colon, and are scattered more diffusely (type 3 cells). Type 2 cells are infrequent. Some type 1 cells (brown ATPase activity) can be seen. Strong ATPase activity occurs in the vessel walls.

rophage family" are indeed heterogeneous, ${ }^{2425}$ This has recently been demonstrated in a variety of situations using a combined analysis similar to that used in this study. ${ }^{91426}$ This heterogeneity of HLA-DR ${ }^{+}$ histiocyte populations, in particular the presence of either strong ACP activity or strong ATPase activity, may have important functional significance. For example, the antigen-presenting interdigitating cells of the lymph node paracortex are stellate or dendritic in appearance, exhibit strong expression of HLA-DR antigens and have strong ATPase activity with weak or negative ACP activity. ${ }^{142} 27$ These cells are thought to be important in the ingestion of soluble antigens and presentation of these antigens to T lymphocytes. ${ }^{27}$ Similar features and role have been shown for Langerhans cells of the $\operatorname{skin}^{28} 29$ although these cells are NA1/34+. ${ }^{14}$ The predominant HLA-DR ${ }^{+}$histiocyte in the small intestine, the type 1 cell, has similar morphology and enzyme activity to the interdigitating cell. The small intestinal mucosa is exposed to a large variety of soluble food antigens, but has only a scanty bacterial population. ${ }^{30}$ This may explain the predominance of HLA-DR ${ }^{+}$cells of the antigen-presenting type within the small intestine. These cells may ingest soluble antigens which have crossed the epithelial barrier and then present these to local helper T lymphocytes, which then, in turn, regulate the immune response to the antigens. The predominance of helper-type $\mathrm{T}$ lymphocytes in the lamina propria of the intestine, and the close relation between these 
lymphocytes and the HLA-DR ${ }^{+}$cells, would support this hypothesis. ${ }^{2}$

The characteristics of the predominant HLA$\mathrm{DR}^{+}$population in the colon (type 2 cell) are those of phagocyctic "scavenger" macrophages. ${ }^{1431}$ Cells of this type are responsible for the ingestion of particulate antigens. ${ }^{27}$ The colon contains an extremely large bacterial flora. ${ }^{32}$ This could account for the presence of a high proportion of type 2 cells in the colonic lamina propria, where they could deal with any penetrating bacterial antigens or cellular debris. Type 1 cells are also present and these may process any soluble antigens entering the mucosa.

In patients with active inflammatory bowel disease there was an increase within the colon of small, irregular $\mathrm{HLA}_{-} \mathrm{DR}^{+} \mathrm{ACP}^{++} \mathrm{NSE}^{+} \mathrm{ATPase}^{+/-}$ (type 3 ) cells. These cells appeared at the expense of the type 2 cells. The findings suggest that the histiocytes in inflammatory bowel disease may be important in pathogenesis, the altered characteristics perhaps representing activation in response to foreign antigen. An increase in the number of macrophages in the mucosa of patients with Crohn's disease has recently been reported, and these macrophages were shown to have large lysosomes containing dense inclusions.$^{33}$ The scattered distribution of type 3 cells resulting from oedema and the inflammatory cell infiltrate may allow $T$ cellmacrophage interactions to take place throughout the mucosa where numbers of helper $T$ and suppressor-cytotoxic $\mathrm{T}$ cells are increased (Selby et al, submitted). Increased turnover of circulating monocytes in patients with inflammatory bowel disease and increased monocyte lysosomal enzyme activity provides evidence for the recruitment of activated macrophages into the intestinal mucosa. ${ }^{34}$ After treatment, the appearances returned to normal, indicating that the alterations seen in the histiocyte populations in inflammatory bowel disease are not primary to the disease process.

Heterogeneity of non-lymphoid, NSE-positive cells thought to have arisen from intestinal mucosa of rats has recently been shown in vitro. ${ }^{36}$ The ability to isolate and study histiocytes from human intestinal lamina propria ${ }^{37}$ will allow closer analysis of the functions of these important cell populations. Such studies, in combination with continued examination of the cellular microenvironment in situ, shall undoubtedly increase our understanding of the immunological mechanisms active in the human intestinal tract.

\section{References}

' Scott H, Solheim BG, Brandtzaeg P, Thorsby E: HLA-DR-like antigens in the epithelium of the human small intestine. Scand $J$ Immunol 1980;12:77-82.
' Selby WS, Janossy G, Goldstein G, Jewell DP. T lymphocyte subsets in normal human intestinal mucosa-the distribution and relationship to MHC-derived antigens. Clin Exp Immunol $1981 ; 44: 453-8$.

${ }^{3}$ Donnellan WL. The structure of the colonic mucosa. The epithelium and subepithelial reticulohistiocytic complex. Gastroenterology 1965;49:496-514.

4 Sawicki W, Kucharczyk K, Szymanskak K, Kujawa M. Lamina propria macrophages of intestine of the guinea pig. Possible role in phagocytosis of migrating cells. Gastroenterology 1977;73:1340-4.

s Klareskog L, Tjernlund UM, Forsum U, Peterson PA. Epidermal Langerhans cells express Ia antigens. Nature 1977;268:248-50.

- Steinman RM, Lustig DS, Cohn ZA. Identification of a novel cell type in peripheral lymphoid organs of mice. III. Functional properties in vivo. J Exp Med 1974;139:1431-45.

' Lampert IA, Pizzolo G, Thomas A, Janossy G. Immunohistological characteristics of cells involved in dermatopathic lymphadenopathy. J Pathol 1980;131:145-55.

8 Janossy G, Tidman N, Selby WS et al. Human inducer and suppressor T lymphocytes occupy different microenvironments. Nature 1980;289:81-4.

- Poulter LW, Duke O, Hobbs S, Janossy G, Panayi G. Histochemical discrimination of HLA-DR-positive-cell populations in the normal and arthritic synovial lining. Clin Exp Immunol 1982;48:381-8.

10 Van-Furth R, Langevoort UL, Schaberg A. Mononuclear phagocytes in human pathology-proposal for an approach to improved classification. In: Van-Furth R, ed. Mononuclear phagocytes in immunity, infection and pathology. Blackwell: Oxford, 1975.

" Poulter LW, Turk JL. Studies of the effect of soluble lymphocyte products on macrophage physiology. II. Cytochemical changes associated with activation. Cell Immunol 1975;20:25-32.

1: Muller-Hermelink HK. Characterisation of the B-cell and T-cell regions of human lymphatic tissue through enzyme histochemical analysis of the human jejunal epithelium in non-tropical sprue. Gastroenterology 1961;40:735-65.

${ }^{13}$ Rowden G, Lewis MG, Sullivan AK. Ia antigen expression on human epidermal Langerhans cells. Nature 1977;268:247-8.

14 Poulter LW, Chilosi M, Seymour GJ, Hobbs S, Janossy G. Immunofluorescence membrane staining and cytochemistry, applied in combination for analysing cell interactions in situ. In: Polak J, Van Moorden S, eds. Immunocytochemistry: practical applications in pathology and biology. Bristol: J Wright, 1982.

is Janossy G, Bollum FJ, Bradstock KF, McMichael A, Rapson N, Greaves MF. Terminal transferase-positive human bone marrow cells exhibit the antigenic phenotype of common acute lymphoblastic leukaemia. J Immunol 1979;123:1525-9.

${ }^{10}$ Selby WS, Janossy G, Jewell DP. Immunological characterisation of intraepithelial lymphocytes of the human gastrointestinal tract. Gut 1981:22:169-76.

17 McMichael AJ, Pilch JR, Galfre G, Mason DY, Fabre JW, Milstein C. A human thymocyte antigen defined by a hybrid myeloma monoclonal antibody. Eur J Immunol 1979;9:20510.

${ }^{18}$ Gomori G. Microscopic histochemistry. Chicago: University Press, 1952.

19 Padykula HA, Strauss EW, Ladman AJ, Gardner FH. A morphologic and histochemical analysis of the human jejunal epithelium in non-tropical sprue. Gastroenterology 1961;40:735-65.

"Spiro HM, Filipe MI, Stewart JS, Booth CC, Pearse AGE. Functional histochemistry of the small bowel mucosa in malabsorptive syndromes. Gut 1964;5:145-54.

"Samloff IM, Davis JS, Schenk EA. A clinical and histochemical study of coeliac disease before and during a gluten-free diet. Gastroenterology 1965;48:155-72. 
${ }^{22}$ Monis B, Mendeloff AI. Studies in ulcerative colitis: TPN-linked dehydrogenases and non-specific esterase in rectal biopsy specimens. Gastroenterology 1965;48:173-84.

${ }^{23}$ Riecken EO, Stewart JS, Booth CC, Pearse AGE. A histochemical study on the role of lysomal enzymes in idiopathic steatorrhoea before and during a gluten-free diet. Gut 1966;7:31732.

${ }^{24}$ Humphrey JH. Differentiation of function among macrophages. In: Microenvironments in haemopoietic and lymphoid differentiation. Ciba Found Symp 1981;84:302-12.

${ }^{25}$ Balfour BM, Drexhage HA, Kamperdijk EWA, Hoefsmit EChM. Antigen-presenting cells, including Langerhans cells, veiled cells and interdigitating cells. In: Microenvironments in haemopoietic and lymphoid differentiation. Ciba Found Symp 1981;84:281-98.

${ }^{26}$ Seymour GR, Poulter LW, Bofill $M$ et al. The reactivity of a monoclonal antibody against cells of the monocyte/ macrophage series in sections of normal and inflamed human tissues. Submitted for publication. 1982.

${ }^{27}$ Hoefsmit EChM, Kamperdijk EWA, Hendrikes HR, Beeten RHJ, Balfour BW. Lymph node macrophages. In: Carr I, Daens WT, eds. The reticuloendothelial system. Vol. 1. Morphology. Oxford: Blackwell Scientific Publications, 1980.

${ }^{28}$ Stingl G, Katz SI, Clement L, Green I, Shevach EM Immunologic functions of Ia-bearing epidermal Langerhans cells. J Immunol 1978;121:2005-13.

${ }^{29}$ Braathen LR, Thorsby E. Studies on human epidermal Langerhans cells. I. Allo-activating and antigen-presenting capacity. Scand J Immunol 1980;11:401-8.

31) Dickman MD, Chappelka AR, Schaedler RW. The microbial ecology of the upper small bowel. Am J Gastroenterol 1976;65:57-62.

${ }^{31}$ Poulter LW, Hobbs S, Bofill M, Janossy G. Immunohistological analysis of delayed type hypersensitivity reactions in man using combined immunofluorescence and cytochemical staining on tissue sections. Submitted for publication. 1982.

${ }^{32}$ Gorbach SL, Nahas L, Lerner PI, Weinstein L. Studies of intestinal microflora. I. Effects of diet, age and periodic sampling on numbers of faecal microorganisms in man. Gastoentrology 1967;53:845-55.

${ }^{33}$ Thyberg J, Graf W, Klingenstrom P. Intestinal fine structure in Crohn's disease. Lysosomal inclusions in epithelial cells and macrophages. Virchows Arch (Pathol Anat) 1981;39:141-52.

${ }^{34}$ Meuret G, Bitzi A, Hammer B. Macrophage turnover in Crohn's disease and ulcerative colitis. Gastroenterology 1978;74:5013.

${ }^{35}$ Mee AS, Jewell DP. Monocytes in inflammatory bowel disease: monocyte and serum lysosomal enzyme activity. Clin Sci 1980;58:295-300.

${ }^{36}$ Steer H. Study of acute localised inflammation of the gastrointestinal tract: the effluent lymph. Gut 1981;22:827-35.

${ }^{37}$ Bull DM, Bookham MA. Isolation and functional characterisation of human intestinal mucosal lymphoid cells. J Clin Invest 1977;59:966-74.

Requests for reprints to: Dr WS Selby, Department of Gastroenterology, John Radcliffe Hospital, Oxford OX3 9DU, England. 